\title{
Application of GIS and Remote Sensing Technique to Change Detection in Land Use/Land Cover Mapping of Igbokoda, Ondo State, Nigeria
}

\author{
James R. Adewumi ${ }^{1}$, James K. Akomolafe ${ }^{2}$, Fidelis O. Ajibade ${ }^{3}$ and Blessing B. Fabeku ${ }^{4}$ \\ ${ }^{1,3}$ Department of Civil and Environmental Engineering, \\ Federal University of Technology, Akure, Nigeria. \\ ${ }^{2}$ Works and Physical Planning Unit, Ondo State University of Science and Technology, \\ Okitipupa, Ondo State, Nigeria \\ ${ }^{4}$ Meteorology Unit, Ondo State University of Science and Technology, \\ Okitipupa, Ondo State, Nigeria. \\ ${ }^{1}$ Email: jradewumi@gmail.com, 22Email: kolawoleakomolafe@gmail.com, \\ ${ }^{3}$ Email: fydelyx87@yahoo.com, ${ }^{4}$ Email: blesong4u@yahoo.com
}

\begin{abstract}
This paper aims at establishing changes in land use and land cover in Igbokoda municipality using Geographic Information System and remote sensing techniques. Three satellite images for three different epochs 1986, 1999 and 2013 were used to produce a land use/land cover map classification for Igbokoda. In determining the extent of land use/land cover changes in the township from 1986 through 1999 to 2013, Landsat images of the town were downloaded from the United State Geological Survey online archive. The images were analyzed using change detection technique (NDVI differencing) along with SRTM 90m DEM of the study area to generate the extent of the changes that have occurred. Ground trotting was carried out to ascertain the accuracy of data and the major changes in the land use/land cover. Results show that vegetation has decreased from $75.04 \%$ in 1986 to $46.81 \%$ in 2013 which was due to increase in population and rapid urbanization. In 1996 the Builtup area covers $19.6321 \mathrm{~km}^{2}$ of the study area but has increased rapidly to $39.1505 \mathrm{~km}^{2}$ in the year 1999 with an average annual increment of $2.025 \mathrm{Km}^{2} /$ year. By the year 2013, the built-up area has increased to $64.1520 \mathrm{Km}^{2}$. Also in the same vein, the bare surface area which was $13.28029 \mathrm{~km}^{2}$ in 1986 was increased to 39.6053 and $50.240 \mathrm{Km}^{2}$ in 1999 and 2013 respectively. On the contrary, the vegetated area of Igbokoda reduced from $196.3046 \mathrm{Km}^{2}$ in 1999 to $122.4680 \mathrm{Km}^{2}$ in 2013. This study has demonstrated that remotely sensed data and GIS based approach is timely and cost effective than the conventional method of analysis, classification of land use pattern effective for planning and management. It further shows that If the rapid change in land use is not properly manage, the situation poses a serious threat to Igbokoda town by increasing surface runoff and susceptibility to flooding.
\end{abstract}

Keywords: GIS, Remote Sensing, Land Use/Land cover, Landsat TM imagery, NDVI

\section{Introduction}

Land cover is one of the most important factors for planning and managing activities concerning the use of land surface, climate change studies and understanding complex interactions between human activities and global change $[1 ; 2]$. The demand for land use/land cover data has

Manuscript History:

Received 15 February, 2016, Revised 21 March, 2016, Accepted 22 March, 2016, Published 31 March, 2016

e-ISSN 2289-7771

Copyright @ 2016 JASPE 
grown in multiple folds over the years as an indispensable means of planning and implementation of developmental projects. Without considering the implications of planning for major developmental projects, there has been unprofessional use of agricultural land and open spaces in an unplanned situation. The data derived for land use/land cover gives insights to better understand land utilization aspects as well as play a vital role in the formulation of policies and programme implementation for development. It is important to note that, land is very important resource to man and it should be better managed for continuous existence and its progress depends on our ability to avoid its mismanagement [3]. Studies have shown that there remains only a few landscapes on Earth which are currently in their natural state. Due to anthropogenic activities, the Earth' surface is being significantly altered and the presence of man and his use of land has had a profound effect upon the natural environment [4;5]. As a result since the early 1980s vast transformations have occurred in the land use and land cover patterns as evidenced by persistent expansion in cultivated land, decrease in natural woodland and grassland in the world $[6 ; 7 ; 8]$. It can therefore be stated that the land use and land cover pattern of a region is an outcome of natural and socio-economic factors and their utilization by man in time and space.

Land-use suitability mapping and analysis is one of the most useful applications of Geographical Information System (GIS) for spatial planning and management [9; 10]. Such analysis is a multicriteria evaluation, which aims at identifying the most appropriate spatial pattern for future land uses according to specified requirements, preferences, or predictors of some activity [11;9]. GIS serves the multicriteria evaluation function of suitability assessment well, providing the attribute values for each location and both the arithmetic and logical operators for combining attributes [12]. Remote sensing has long been an effective means for land cover mapping with its ability to quickly collect information on a large regional scale, and many land cover maps on global and regional scales have been produced in recent years using remote sensing data $[13 ; 14]$.

Change detection is the technique, which is used for the assessment of resources, where multidate images are compared to find out the type and amount of change that have occurred. The various applications of change detection are in agricultural, hydrological, forestry, environmental and ecological fields [15]. The important goal in change detection is to compare spatial representations of two points in time by controlling all variances caused by differences in variables of non-interest (i.e. variation in orbital and platform altitudes) and to measure change caused by differences in variables of interest. Currently, land use/land cover change detection relies primarily upon some types of techniques: map-to-map and image-to-image comparison. The goal of remote sensing change detection according to [16] is to:

a) detect the geographic location of change found when comparing two (or more) dates of imagery;

b) identify the type of change if possible (e.g., from forest to agriculture); and

c) quantify the amount of change.

From the ecological perspective, land degradation is seen as damage to the healthy functioning of land-based ecosystems [17]. Soil degradation phenomena occurs via a complex interaction between natural (e.g. soil properties and climate conditions) and human factors (e.g. over-grazing, overcultivation and deforestation) [18]. The main types of land degradation factors identified in the north Nile Delta include: salinity, compaction and water logging as well as water erosion which can be attributed to the Mediterranean Sea level rise [17].

Land degradation can be investigated in different ways, such as direct field observation and remote sensing. In comparison to field methods, the remote sensing technique is more cost-effective and time-efficient in which a huge land area can be monitored using one image. A large number of studies have been carried out using different methods of remote sensing and GIS to determine the extent of degradation. Remotely sensed imagery is appropriate for revealing land that has been affected by degradation to various levels [19]. Furthermore, remotely sensed data is effective in identifying and mapping land degradation and modeling soil loss $[20 ; 21 ; 22 ; 23]$. The swift growth of 
Igbokoda area and its agricultural area have probably resulted very rapidly and have had a detrimental effect on the environment. Due to this, multi-temporal Landsat TM imagery for assessment land cover change is chosen as appropriate tool for this study. The study therefore is aimed at detecting the land use/land cover change in Igbokoda municipality using landsat TM imagery \{Landsat 5 (TM), Landsat 7 (ETM+) and Landsat 8 (LC) .

\section{Research Methodology}

\subsection{Descriptions of the Study Area}

Igbokoda town extends from latitude 6' $20^{\prime \prime}$ N to 6'24', $\mathrm{N}$ and longitude 4'45' $\mathrm{E}$ to 4'48' $\mathrm{E}$. The town comprises of many quarters. It is about $24 \mathrm{~km}$ from the coast of Atlantic Ocean. The existing road network which links the town with the neighbouring towns such as Okitipupa, Aboto, Mayin, Igbo Nla, among others, further promotes the town accessibility to regional centers. History has it that the indigenes of Igbokoda are Ilajes who in the course of searching for dry land to promote their economic activities and make contact with the people of upland, settled in the present Igbokoda town.

Traditionally, the Ilajes are highly successful traders, merchants, fishermen, farmers and boat builders. Bitumen and crude oil are found in large quantities in this area which make Ondo State as a recognized oil-producing State in South-West Nigeria. Culturally, Ilaje people celebrates annually, Boat Regatta, Ilaje Day, Twins Festival, Olokun Festival, and Christian anniversaries by various churches [24].In addition, Ilaje is also blessed with agricultural raw materials like fish, poultry, maize, palmoil vegetables, timber, rafia, poultry okro, cocoyam, banana, cassava and piggery. The natural environment of Ilaje land is particularly suitable for the development of large scale rice plantation and salt industry. It is believed that the town has undergone many evolutionary processes of political administrative, spatial, demographic and economic changes. The map of Ondo State showing Ilaje Local Government and Igbokoda road map and rivers are shown in Figures 1 and 2. 


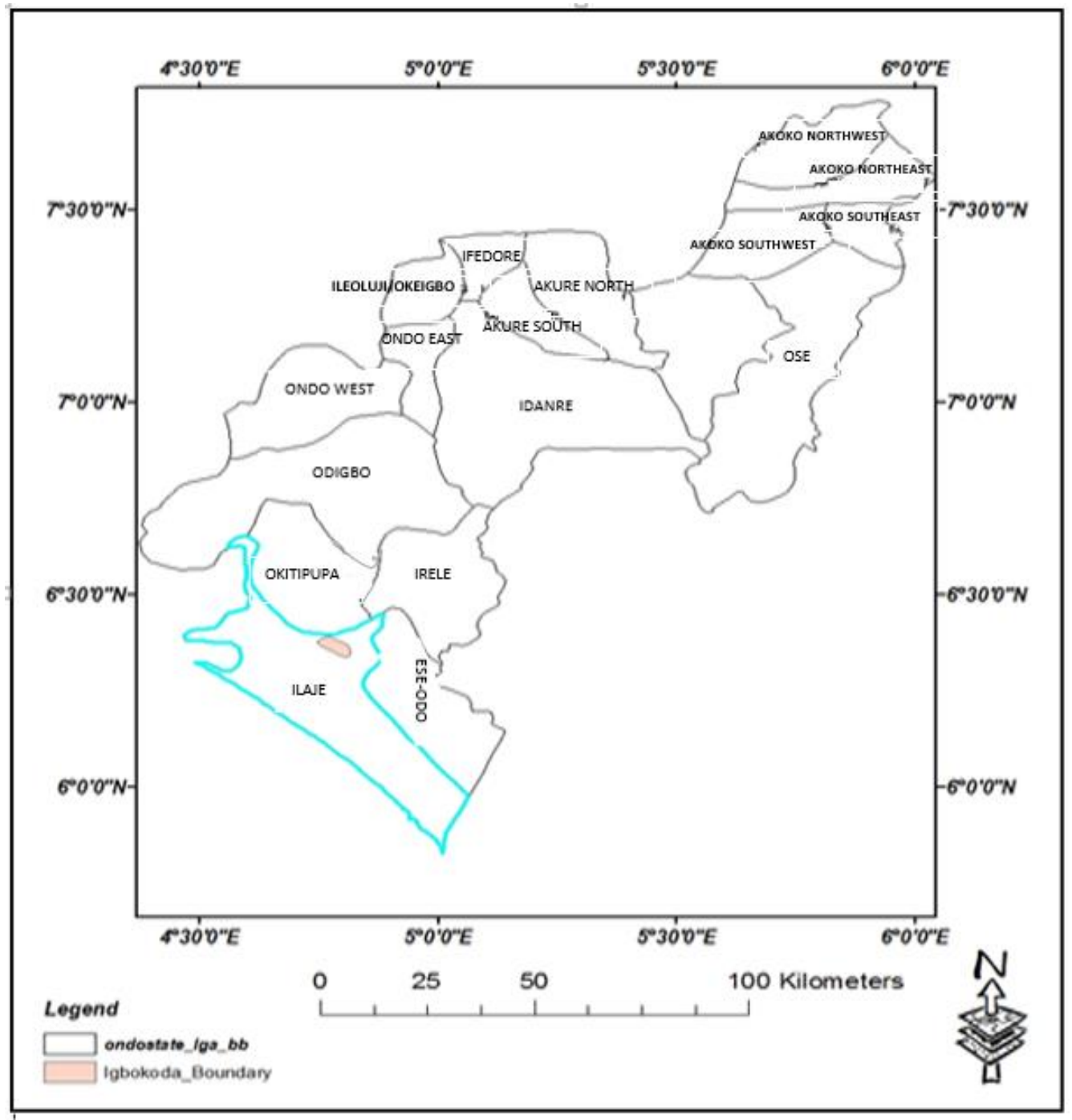

Figure 1: Map of Ondo State showing Geographical Location of the Study Area (Igbokoda) within Ilaje Local Government Area 


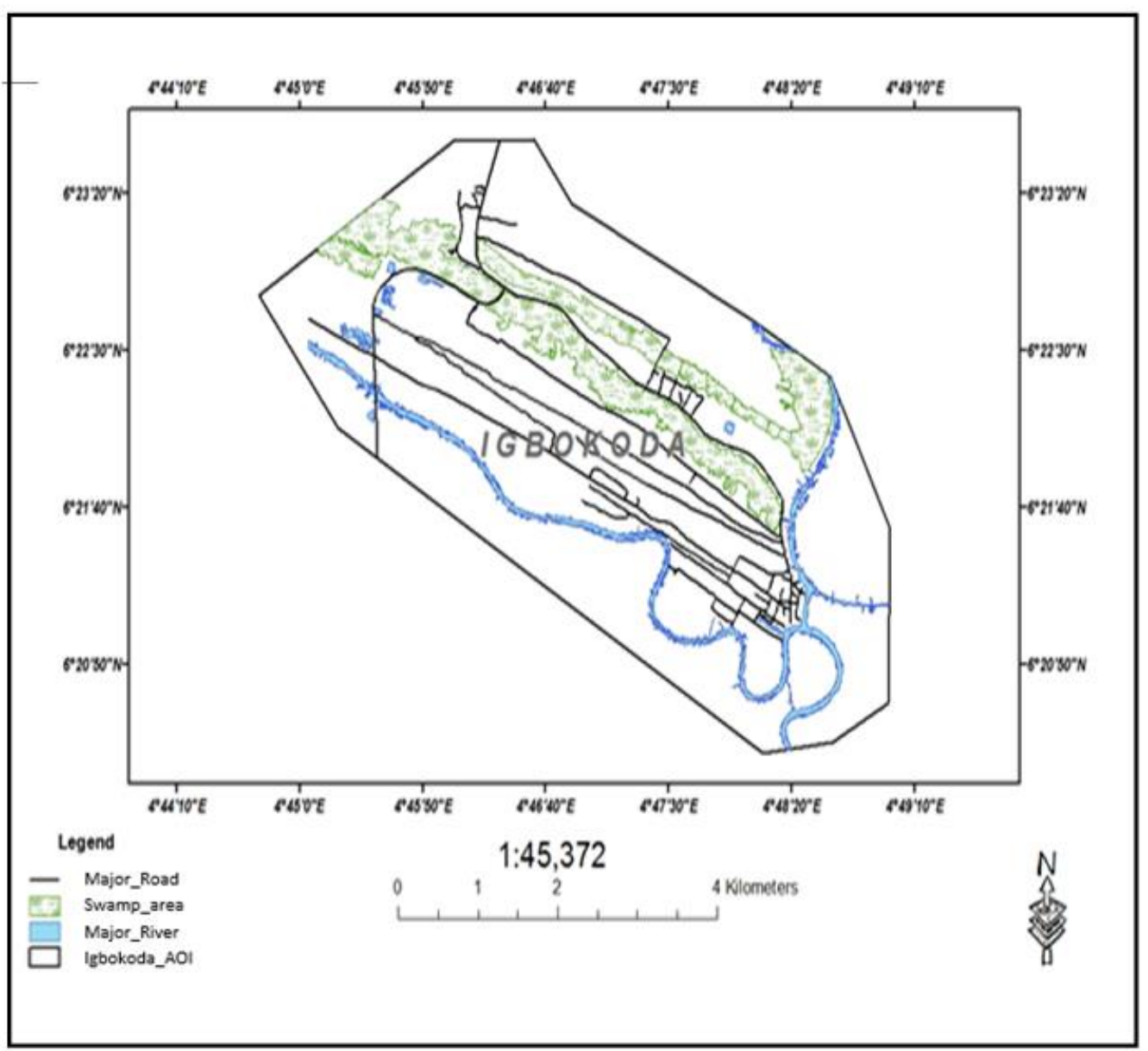

Figure 2: Digitized Map of the Study Area showing the Road Network and other Features

\subsection{Data Acquired, Sources and Software Packages}

The steps involved in data collection are the downloading of Landsat satellite images, Ikonos Image and Aster SRTM DEM from USGS online data archives (www.glovis.usgs.gov); clipping of the area of interest, data processing, generation of the colour composite images and vegetation cover (VC) images, generation of Normalized Differential Vegetation Index (NDVI) map, generation of digital elevation model (DEM) and creation of cadastral map.

Other software packages used are:

a) ArcGIS 9.3 - This is used to create map boundary of the study area in this project, also the power option of IDW is used to interpolate the SPI results and its reclassification to obtain Drought Spatial Pattern maps. NDVI calculations and their images are also done here.

b) Erdas Imagine 9.1 - this is used for displaying and clipping area of interest from the downloaded imageries for it to be imported into Ilwis environment for further processing.

c) Ilwis 3.5 - This is used to perform the bands staking in order to obtain the color composite and image classification.

d) Microsoft Excel is used for SPI analysis and also in producing the graph. 


\subsubsection{Satellite Data}

These are sets of information about the features on the surface of the earth remotely acquired by the sensors onboard via the means of electromagnetic energy, stored in the form of digital picture (e.g. geotiff).

\subsubsection{SRTM 90m DEM}

The Shuttle Radar Topography Mission (SRTM) was launched on February 11, 2000 and was a joint project between U.S. National Geospatial Intelligence agency (NGA) and U.S. National Aeronautics and space Administration that obtained digital elevation data of the Earth's surface on a near-global scale (almost $80 \%$ of the earth's surface) between $56^{\circ} \mathrm{S}$ and $60^{\circ} \mathrm{N}$ [25]. Edited data became available by year 2004 at a spatial resolution of one arc second for the United States (approximately $30 \mathrm{~m})$ and three arc second $(90 \mathrm{~m})$ for the rest of the world $[25 ; 26]$. The production of a near global SRTM data has enabled global assessments especially on extraction of drainage networks and upstream catchment areas in the flood risk zones [27].

SRTM 90 m DEM of the study area (Igbokoda) is derived from United State Geological Survey/National Aeronautics and Space Administration/Shuttle Radar Topography Mission (USGS/NASA SRTM) in which data already in decimal degrees and datum WGS84. The data is downloaded from the CIAT - CSI SRTM website (http://srtm.csi.giar.org). It is projected to the UTM coordinate system and clipped to the extent of the study area.

\subsubsection{Landsat Data}

The Landsat program originated in the United States in July 23, 1972, Landsat 1 was launched as the first Earth Observation Satellite with the objective of studying and monitoring landmasses on the Earth Surface. At the time of its launch, it was known as Earth Resources Technology Satellite ERTS [28], seven more Landsat satellites had been launched since then as Landsat 2, 3, 4, 5, 6, 7 and 8.

In this study, Landsat 5 (TM), Landsat 7 (ETM+) and Landsat 8 (LC) imageries are used. Landsat 5 was launched on $1^{\text {st }}$ March, 1985. In addition to the multispectral scanner system that was available in the first four Landsat satellites, Landsat 5 is developed with a unique feature, a sensor that has better spatial and spectral resolution that enable the satellite to capture image from a wider view [29]. This feature is the Thematic Mapper (TM). Landsat 7 was launched on $15^{\text {th }}$ April, 1999 with an Enhanced Thematic Mapper plus (ETM+). Both Landsat satellites have seven spectral bands but Landsat 7 ETM+ has an additional eight band known as panchromatic band with $15 \mathrm{~m}$ spatial resolution and it responds spectrally from the green through the near infra-red region of the wavelength of the electromagnetic spectrum [30]. Table 1 shows the spectral sensitivity of the seven bands of Landsat satellites, the panchromatic band and their applications. 
Table 1: Spectral bands of Landsat Satellites and their applications

\begin{tabular}{|c|c|c|c|c|}
\hline $\begin{array}{l}\text { Band } \\
\text { No }\end{array}$ & Spectral response & $\begin{array}{l}\text { Wave } \\
\text { length }\end{array}$ & Resolution & Application \\
\hline 1 & Blue - green & $\begin{array}{l}0.45- \\
0.52 \mathrm{~nm}\end{array}$ & $30 \mathrm{~m}$ & $\begin{array}{l}\text { Useful in mapping aquatic } \\
\text { ecosystem and classification of } \\
\text { forest features }\end{array}$ \\
\hline 2 & Green & $0.52-0.60$ & $30 \mathrm{~m}$ & $\begin{array}{l}\text { Useful in } \\
\text { discrimination } / \text { vegetation } \\
\text { monitoring and identification } \\
\text { Of manmade features }\end{array}$ \\
\hline 3 & Red & $\begin{array}{ll}0.63 \quad- \\
0.69 \mathrm{~nm}\end{array}$ & $30 \mathrm{~m}$ & $\begin{array}{l}\text { Useful in identification of plant } \\
\text { species, vegetation health } \\
\text { monitoring and manmade } \\
\text { features }\end{array}$ \\
\hline 4 & Near infra-red & $\begin{array}{l}0.76-0.90 \\
\mathrm{Nm}\end{array}$ & $30 \mathrm{~m}$ & $\begin{array}{l}\text { Useful in vegetation monitoring } \\
\text { water body discrimination and } \\
\text { definite water/land interface }\end{array}$ \\
\hline 5 & Near infra red (SWR) & $\begin{array}{ll}1.55 \\
1.75 \mathrm{Nm}\end{array}$ & $30 \mathrm{M}$ & $\begin{array}{l}\text { Useful in monitoring moisture } \\
\text { content in vegetation and } \\
\text { distinguishing between clouds } \\
\text { and snow }\end{array}$ \\
\hline 6 & Thermal infra-red & $\begin{array}{ll}10.40 \\
12.50 \mathrm{Nm}\end{array}$ & $\begin{array}{l}60 \mathrm{~m} \quad 130 \mathrm{~m} \\
(\mathrm{ETMT}), 125 \\
(\mathrm{TM})\end{array}$ & $\begin{array}{l}\text { Useful in monitoring volcanic } \\
\text { features, surface temperature and } \\
\text { cloud differentiation }\end{array}$ \\
\hline 7 & Mid infra-red (SWIR) & $\begin{array}{ll}2.08 & -2.35 \\
\mathrm{Nm} & \end{array}$ & $30 \mathrm{M}$ & $\begin{array}{l}\text { Useful in soil and geological } \\
\text { mapping especially in mineral } \\
\text { and rock discrimination }\end{array}$ \\
\hline 8 & $\begin{array}{l}\text { Green to Near infra red } \\
\text { panchromatic band } \\
(\mathrm{ETM}+\mathrm{ONLY})\end{array}$ & $0.5-0.9 \mathrm{Nm}$ & $15 \mathrm{M}$ & $\begin{array}{l}\text { More sparally detailed mapping } \\
\text { of land features }\end{array}$ \\
\hline
\end{tabular}

Source: $[28 ; 29 ; 30 ; 31 ; 32]$

Landsat images are generally known to be efficient, simple and first choice when it comes to mapping of flood vulnerable areas [33], three Landsat Images are downloaded from [34]. Table 2 shows a list of Landsat images acquired and their dates. 
Table 2: Summary of Landsat Images Acquired

\begin{tabular}{|l|l|l|l|}
\hline S/N & Landsat Satellite & Date & Pathrow \\
\hline 1. & Landsat 5 (TM) & 25 April, 1986 & $190 / 056$ \\
\hline 2. & Landsat 7 (ETM+) & 13 December, 1999 & $190 / 056$ \\
\hline 3. & Landsat 8 (LC) & 12 June, 2013 & $190 / 056$ \\
\hline
\end{tabular}

\subsubsection{High Resolution Imagery----Ikonos Image}

Geometrically rectified high resolution imagery (Ikonos image) of resolution of $0.8 \mathrm{~m}$ covering the study area was obtained. Road networks and building across the town was digitized. Properties that will be affected were mapped out considering the buffering zone.

\subsubsection{Vector Data}

The study area boundary map used to clip out area of interest from the satellite imageries was curved out from the local government boundary map and Nigerian Administrative map on the scale of 1:15,140,906 which was obtained from National Space Research and Development Agency, Abuja (NASRDA).

\subsubsection{Clipping of study area}

Each composite of the satellite imageries used in this study were susbseted using Igbokoda boundary map gotten from NASRDA to delineate the spatial extent of the area of interest over each of the satellite scene. This was done using processed the vector data in Erdas Imagine 9.0 and later export to Iliwis 3.5 and ArcGIS 9.3 environment for further analysis.

\subsubsection{Data Re-processing}

The satellite imageries downloaded have already been corrected from the manufacturer radiometrically and geometrically to raster image (Geotiff). The images coordinate is in projection coordinate (WGS_84).

\subsubsection{Panchromatic Sharpening}

Pan- sharpening involves the fusion of the high resolution $(1.5 \mathrm{~m})$ panchromatic band/image with the lower resolution bands $(30 \mathrm{~m})$ of the same Landsat Image [35; 36; 37]. The three (3) Landsat composite images were pan- sharpened with their respective panchromatic images which enhanced their respective features for the purpose of image recognition while classifying the Images.

\subsubsection{Generation of Composite image and Land Cover image}

Colour composite involves stacking or combination of different bands (band 4, band 3, \& band 2) together to produce a false colour composite image purposely for features recognition while classifying.

Land Cover (LC) image comprises of vegetation cover types which is a prime indicator of spatial impact extent and flood plain since their population and growth are greatly affected by human 
anthropogenic activities and prolong accumulation of flooding water. LC image for respective epoch was obtained after classifying the colour composite image using maximum likelihood method of image classification. The classification was done based on the selection of a set of pixels been assigned to each of the four classes created (Land cover categories) which are bare surface, built-up area, vegetation and water body.

Table 3: Land covers classification categories

\begin{tabular}{|l|l|l|}
\hline S/N & Classes & Colour \\
\hline 1 & Bare Surface & Light Brown \\
\hline 2 & Built-up Area & Red \\
\hline 3 & Vegetation & Deep Green \\
\hline 4 & Water Body & Blue \\
\hline
\end{tabular}

The above (Table 3) Land Cover categories were arrived after a brief reconnaissance survey had been carried out to obtain information about the study area.

\subsection{Generation of Greenness Index (NDVI) and Greenness Index image}

NDVI calculation was performed to find out the changing pattern of the vegetation during the selected period of this study due to satellite data available (1986, 1999 and 2013). The following algorithm developed by [38] was used for the analysis.

$N D V I=\frac{(N I R-R)}{(N I R+R)}$

Where: NIR and R is the reflectance in the near-infrared (band 4) and red (band 3) portion of Electromagnetic spectrum respectively. NDVI is the most widely used index in studying vegetation related issue [39]. It can also be used to indicate deficiencies/improvement in rainfall and portray drought/flood event impact on vegetation in a particular geographical location both timely and spatially. NDVI is an important factor in flood risk analysis and the technique is used for analyzing the response of vegetation cover to flooding characteristics [40]. The NDVI is calculated from two bands in the Landsat images: the near infra-red (NIR) band (band 4) and the red band (band 3). The NDVI takes advantage of the feature of these two bands that is the high reflectance for plants materials of the NIR band and the chlorophyll pigment absorption of the red band to produce an image that presents greenness or relative biomass $[41 ; 42 ; 43]$. In order to generate Greenness Index (GI) map, the resulted NDVI maps were classified in ArcGIS 9.0 environment using the threshold NDVI values in the Table 4 
Table 4: Greenness Index threshold values

\begin{tabular}{|l|l|}
\hline Land Cover Categories & NDVI Values \\
\hline Dense Vegetation & $+0.04-+1.00$ \\
\hline Less Dense Vegetation & $+0.04-+0.07$ \\
\hline Bare Surface Area & $-0.08-+0.04$ \\
\hline Water Body & $-0.08--1.00$ \\
\hline
\end{tabular}

Greenness Index (GI) map reveals the spatial extent of vegetation cover over the selected parts of the study area.

\subsection{Elevation of the study area above sea level}

The elevations of the study area mapped out from the re-sampled Ikonos image were obtained from SRTM 30M DEM data in Arc GIS 9.3 environment.

\section{Result and Discussion}

\subsection{Vegetation Cover Index Maps}

Normalized Differential Vegetation (NDVI) Index maps over the study area (Igbokoda) for the year 1986, 1999 and 2013 as generated from NDVI analysis are shown in Figure 3. Each of these NDVI maps has NDVI value on their respective legend ranging from -1 to +1 , with the positive values indicating Vegetative part and the negative values denoting the water-body/built-up area while the values very close to zero shows the areas of bare soil/surface. The Greenness Index Maps as shown in Figure 3 were obtained from the NDVI maps produced for the study area. These maps consist of three distinct features namely; Vegetation, water-body/Built-up area and Bare-Surface (Figure 4), purposely done for easy assessment of change in the vegetative part of the area of interest over the study area.

Most of the spatial extent of Igbokoda as based on its geographical location (coastal area) is covered with wetland (swampy area). These wetlands are responsible for vegetation growth over the area which in turns play important role in every flood event that takes place. The vegetation forms a kind of resistant to the free flow of water from the swamps into the residential area whenever there is heavy downpour. It could be noted from Figure 4 that there is reduction in vegetation across the study area to the recent year 2013 from 1986 as two-third of the whole spatial extent was revealed to be cover with bare surface in the year 2013. 


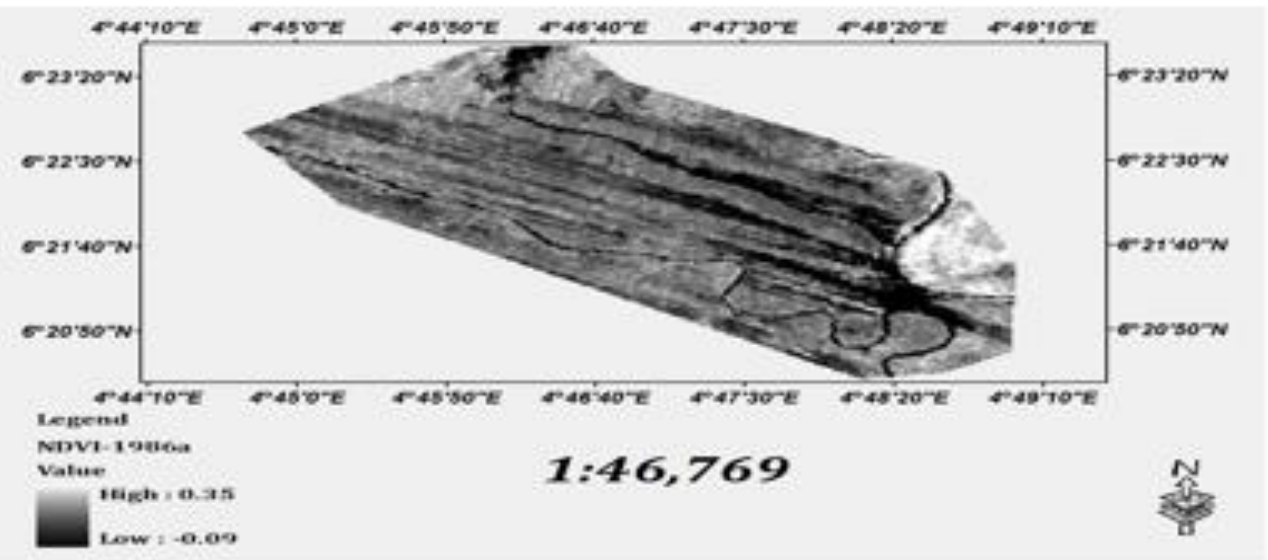

(a)

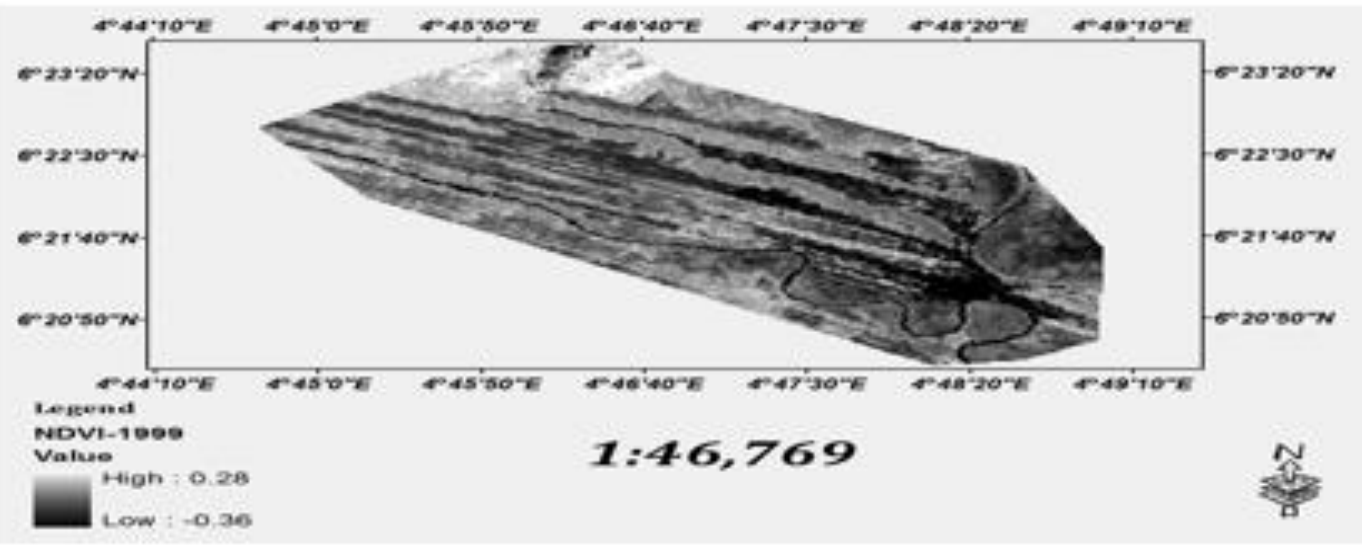

(b)

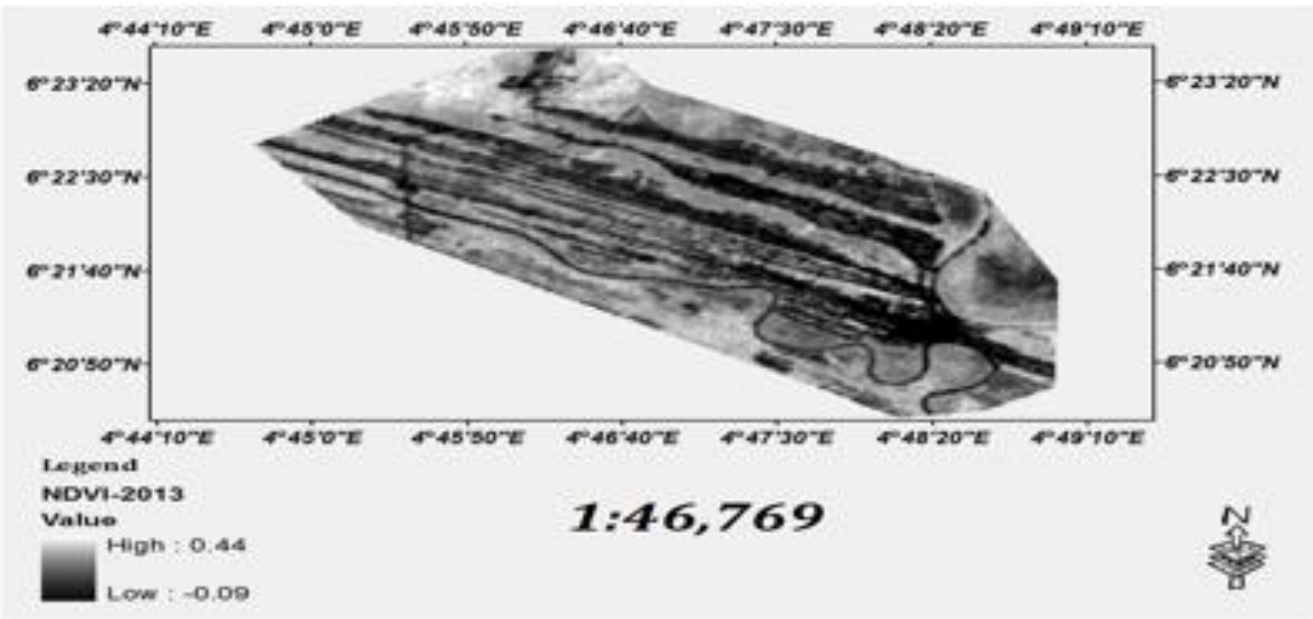

(c)

Figure 3: Normalized Differential Vegetation Index Maps part of the Study Area (Igbokoda): (a) 1986, (b) 1999 and (c) 2013 


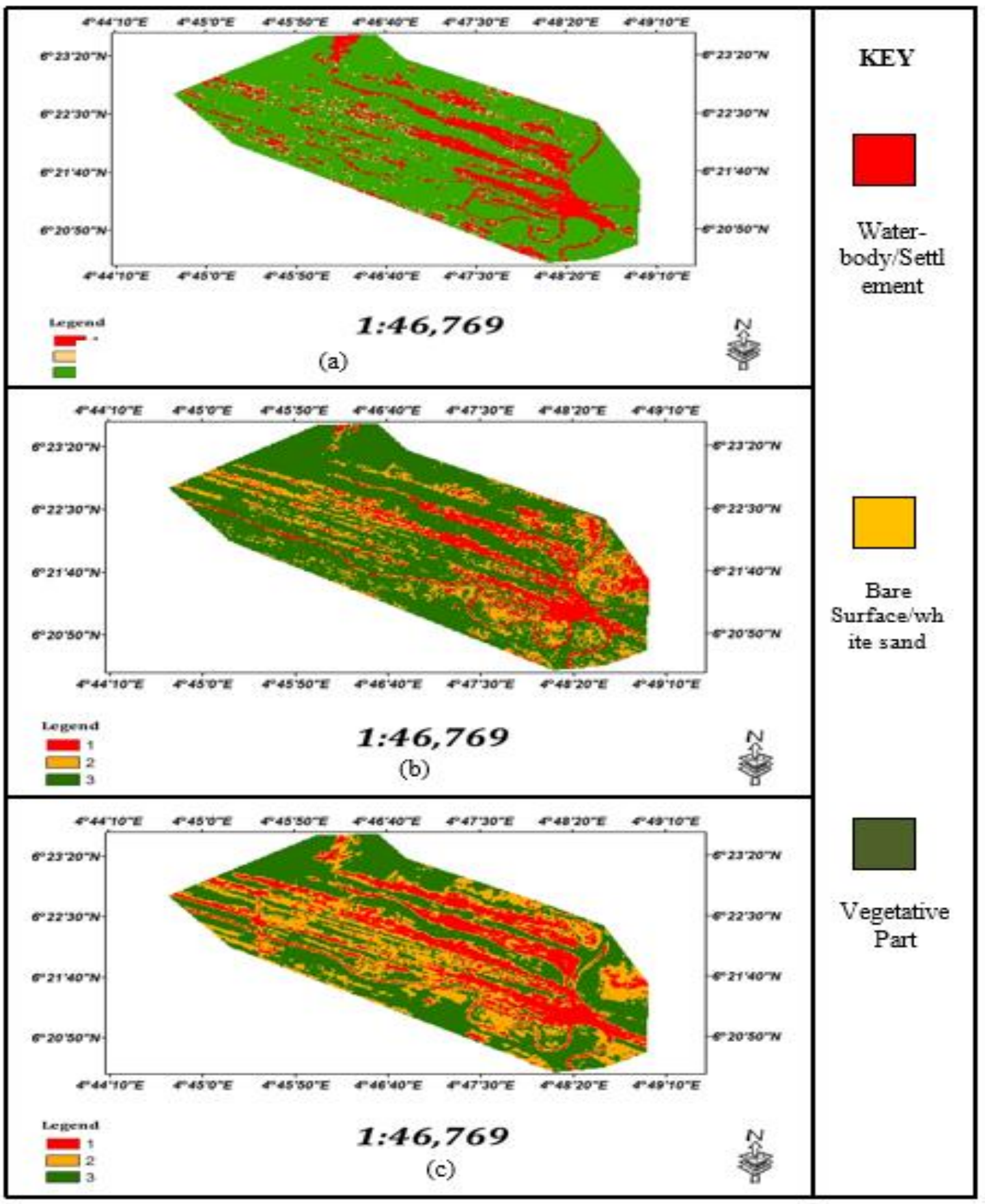

Figure 4: Greenness Index Map over the study area for periods: (a) 1986, (b) 1999 and (c) 2013

Greenness Index Map also pointed to the fact that the built up area have almost similar reflectance's in both the Near-Infrared band and Visible or red band as they always revealed negative NDVI value. 


\subsection{Land Cover Distribution Maps}

Land use/Land cover geo-analysis of Igbokoda was carried out in order to depict the spatial extent to which, not only the vegetation has changed but the contribution of anthropogenic activities in this geographical location to flood occurrence. This become highly imperative in vegetation assessment analysis as related to flood event in any geographical location since vegetation depletion could result to reduction of the surface resistivity to water accumulation and high susceptibility to surface run off (water flow).

Figure 5 shows the classified Landsat image over the study area for the year 1986, 1999, and 2013 and simply revealed the change in the vegetation cover (the green tone), water bodies (the blue tone) and other features as depicted on their respective legend.

Presented in Table 5 is the Landuse/Land cover (LULC) result. The result was converted into percentage as presented in Table 6 and average to determine the rate at which each of the land cover category has change over the time. All the results gotten from the classified images were shown in Table 6 and summarized in Figure 6 for easy interpretation. 


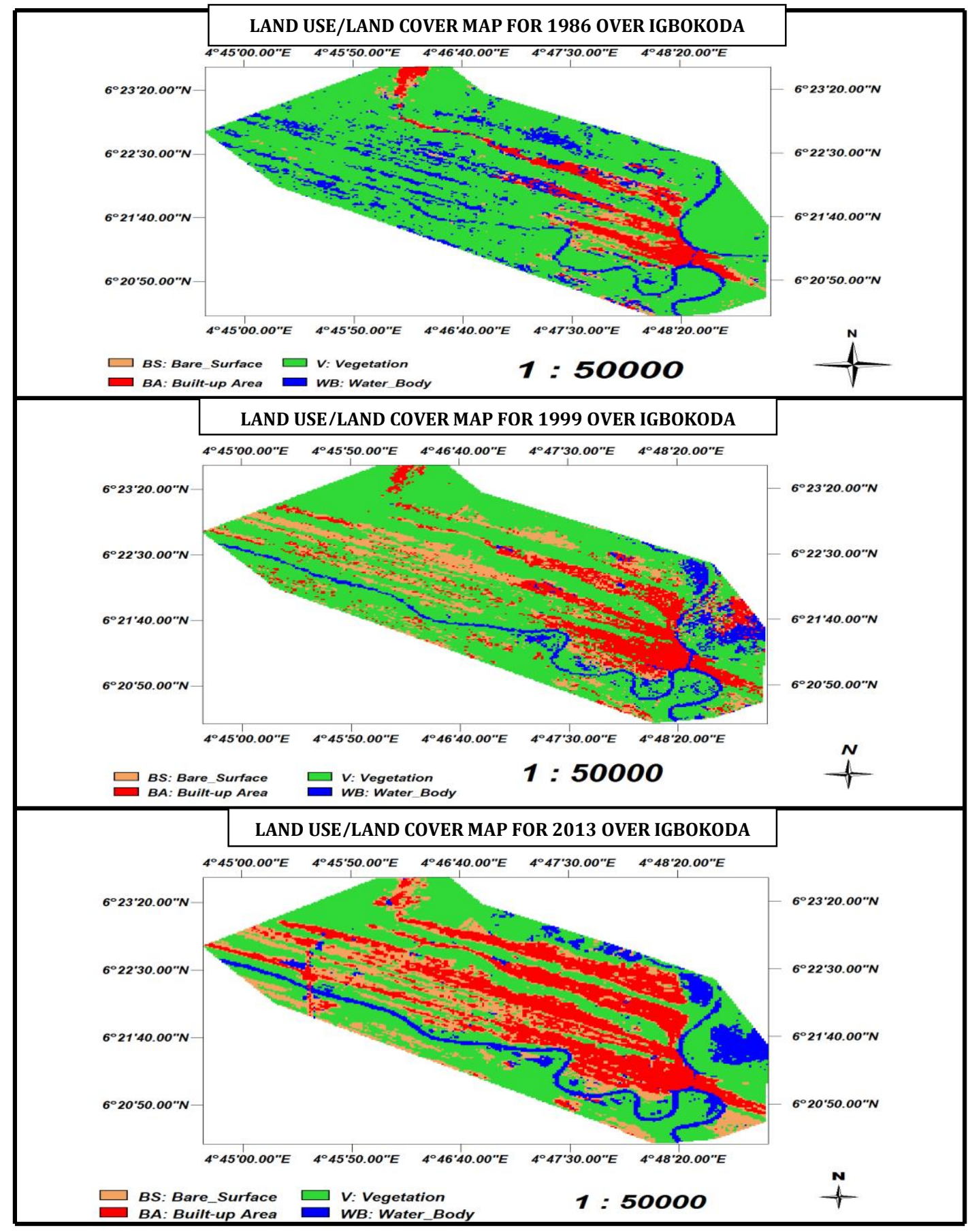

Figure 5: Classified Landsat image over study area for the year 1986, 1999, and 2013 
Table 5: The spatial extent of land cover over Igbokoda after classification

\begin{tabular}{|l|l|l|l|l|l|l|}
\hline Land Cover types & 1986 Area $\left(\mathbf{k m}^{2}\right)$ & Area in \% & 1999 Area $\left.\mathbf{( k m}^{\mathbf{2}}\right)$ & Area in \% & $\mathbf{2 0 1 3}$ Area $\left(\mathbf{k m}^{\mathbf{2}}\right)$ & Area in \% \\
\hline Bare Surface & 13.28029 & 5.08 & 39.60531 & 15.14 & 50.240 & 19.20 \\
\hline Built-up Area & 19.63208 & 7.50 & 39.15045 & 14.97 & 64.152 & 24.52 \\
\hline Vegetation & 196.30458 & 75.04 & 165.2766 & 63.18 & 122.468 & 46.81 \\
\hline Water Body & 32.38441 & 12.38 & 17.56897 & 6.72 & 24.741 & 9.46 \\
\hline TOTAL & 261.6014 & 100 & 261.6014 & 100 & 261.601 & 100 \\
\hline
\end{tabular}

Table 6: Comparison of areas and rates of change of the four Landuse/Landcover classes between 1986-1999 and 1999-2013 for study area (Igbokoda)

\begin{tabular}{|c|c|c|c|c|c|c|c|}
\hline $\begin{array}{l}\text { Land Cover } \\
\text { types }\end{array}$ & $\begin{array}{ll}1986 & \text { Area } \\
\left(\mathrm{km}^{2}\right) & \end{array}$ & $\begin{array}{ll}1999 & \text { Area } \\
\left(\mathrm{km}^{2}\right) & \end{array}$ & $\begin{array}{ll}2013 & \text { Area } \\
\left(\mathrm{km}^{2}\right) & \end{array}$ & $\begin{array}{l}\text { Change between } \\
1986 \text { and } 1999 \\
\left(\mathrm{Km}^{2}\right)\end{array}$ & $\begin{array}{l}\begin{array}{l}\text { Average rate of } \\
\text { change } \\
\left(\mathrm{km}^{2} / \mathbf{y r}\right)\end{array} \\
\end{array}$ & $\begin{array}{l}\text { Change } \begin{array}{r}\text { between } \\
1999 \\
\left(\mathrm{~km}^{2}\right)\end{array} \text { and } 2013 \\
\end{array}$ & $\begin{array}{l}\text { Average rate of } \\
\text { change } \\
\left(\mathrm{km}^{2} / \mathrm{yr}\right)\end{array}$ \\
\hline Bare Surface & 13.2803 & 39.6053 & 50.2400 & 26.325 & 2.025 & 10.6347 & 0.7596 \\
\hline Built-up Area & 19.6321 & 39.1505 & 64.1520 & 19.5184 & 1.5014 & 25.0016 & 1.7858 \\
\hline Vegetation & 196.3046 & 165.2766 & 122.4680 & -31.02 & -2.3868 & -42.8086 & -3.0578 \\
\hline Water Body & 32.3844 & 17.5690 & 24.7410 & -14.8154 & -1.1397 & 7.1720 & 0.5123 \\
\hline
\end{tabular}

Note: A decrease carries Negative sign while an increase carries positive sign 


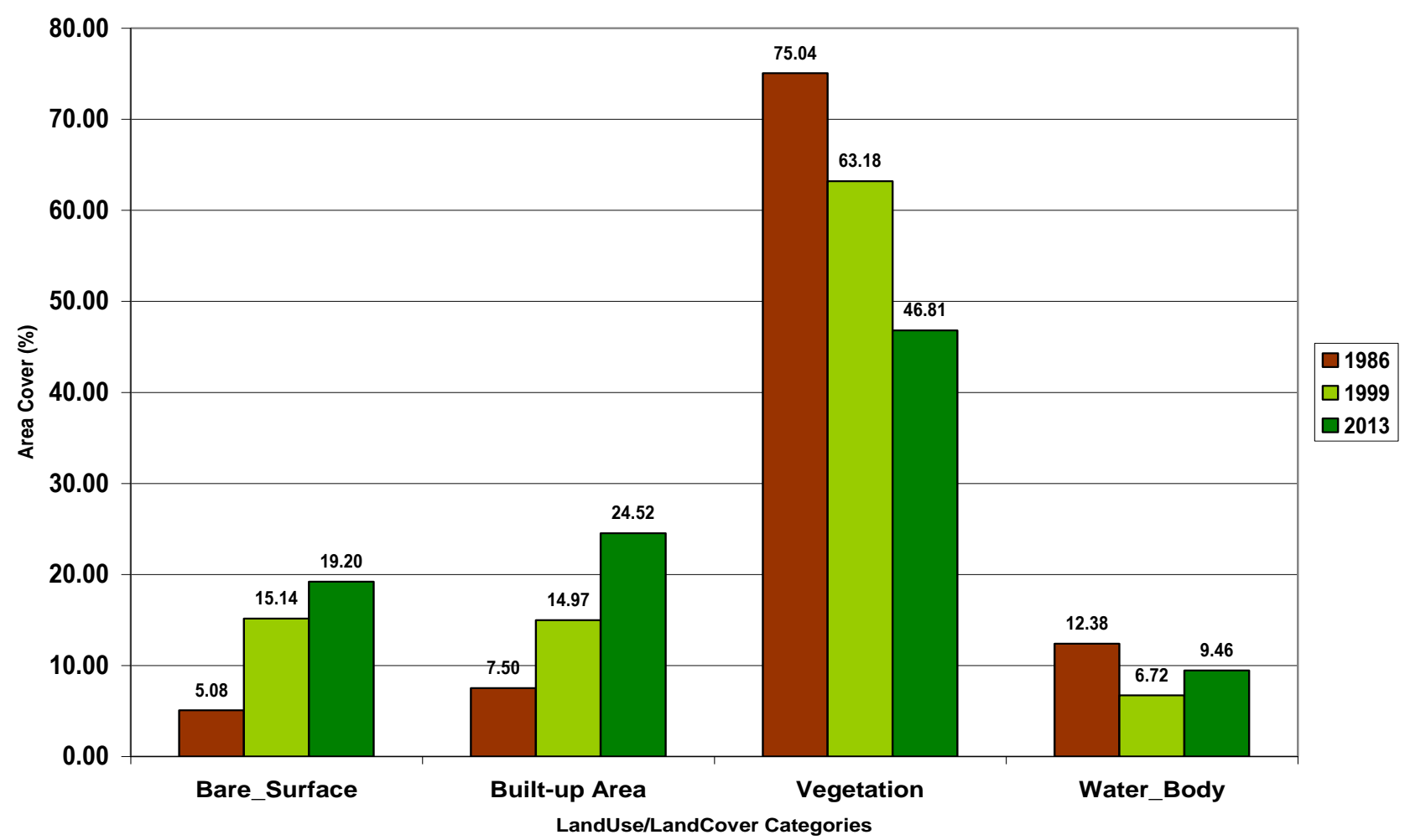

Figure 6: Percentage Area of the Land Cover Categories for 3 different years considered over Igbokoda

Figure 6 show that there exists a change in each of the Landuse/Landcover categories considered in this study (that is, Bare Surface, Built-up Area, Vegetation and water body). Vegetation which formed a resistive feature against flood has actually decreased from $75.04 \%$ in 1986 to $46.81 \%$ in 2013 which was due to increase in population resulting in high urbanization. The portion within the study area that reflects the influence of human activities (i.e., anthropogenic activities) was denoted as Built-up area. The Built-up area covers 1963.21 ha $\left(19.6321 \mathrm{~km}^{2}\right)$ of entire study area which was $7.50 \%$ of the whole spatial extent in 1986 , but has increased to $14.97 \%$ that is 3915.05 ha $(39.1505$ $\mathrm{km}^{2}$ ) in the year 1999 and by the year 2013, 24.52\% increment was recorded for Built-up (Table 5 and Figure 6). Though, most of these built up are situated in the area associated with high elevation and along the road sides that had already been sand filled during road construction activity.

As depicted in Figure 7, areas associated with lower slope angles within the closer proximity of the stream channels receives more flooded water faster than high elevated areas. The slope of the basin influences both the speed of runoff and the rate of infiltration of water. The areas with low slope are associated with higher infiltration rate and do experienced decrease in surface runoff which in turns increases their susceptibility to the risk of flooding [44]. Igbokoda township is characterized by low elevation slope angles with its major residential part fall within elevation ranging from $10 \mathrm{~m}$ to $20 \mathrm{~m}$ above sea level and slope angles less than or equals 7 degrees (Figure 7). Hence, land use planners with the intention of developing infrastructures with this information at their disposal will ensure such developments are either built on natural or artificially made higher grounds to avoid flooding. 


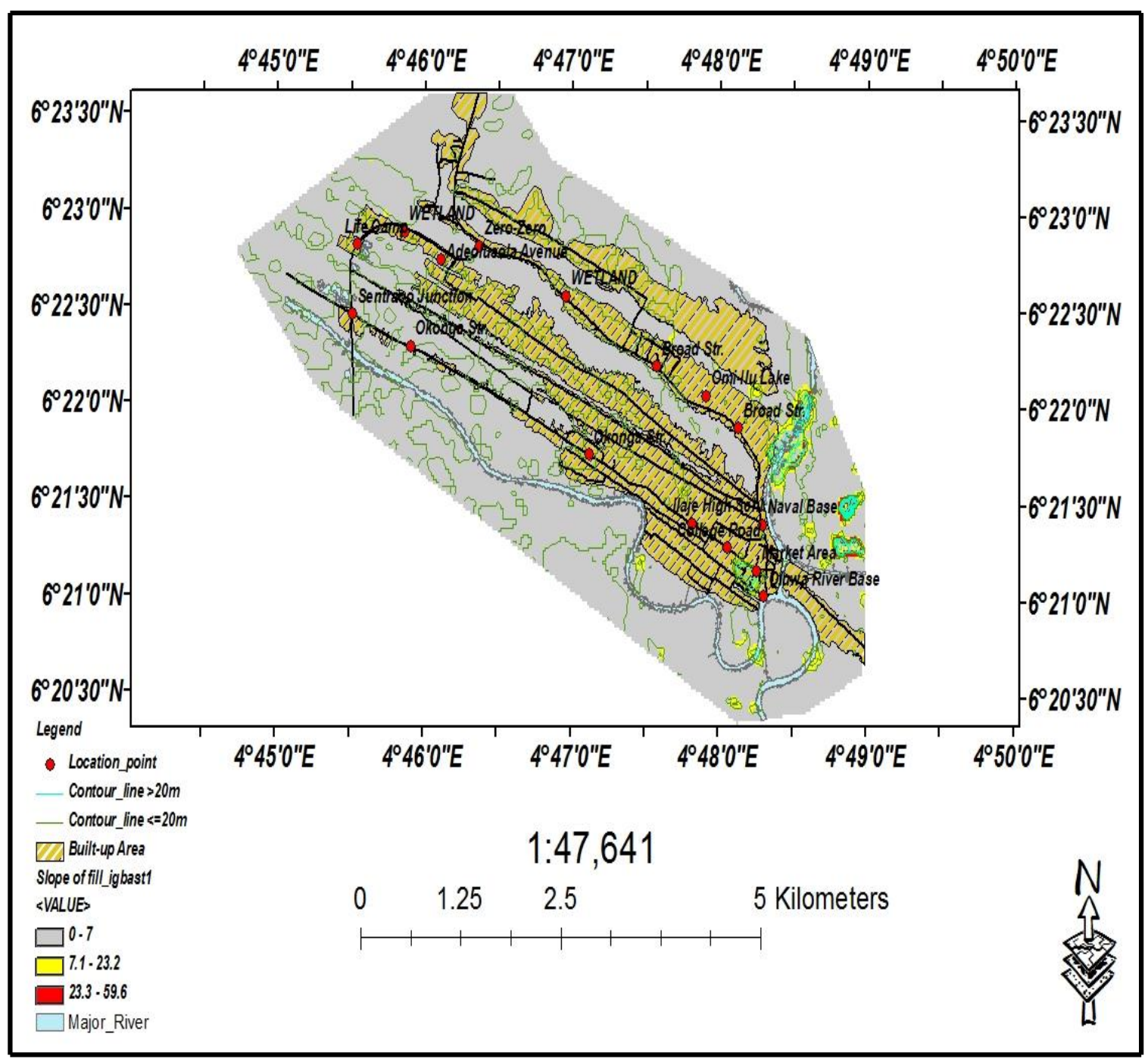

Figure 7: The map of the study area showing the elevation and slope angles

\section{Conclusion}

GIS is a valuable tool to better manage, clarify and maintain resources. It is a proven decision support system employing land cover change maps among other data resources that are major products created from remotely sensed data. This study has established the fact that there has been a reduction in the vegetation cover over the area in 1986 towards 1999 and the decrease was still on the course towards 2013 which simply means there has been less hindrances to flow of water over the area and thereby enhancing the surface runoff. It could also be concluded from the DEM analysis that Igbokoda is a low land area with very low slope angle which make it highly susceptible to flooding.

\section{References}

[1] Jia, K., Wei, X.Q., Gu, X.F., Yao, Y.J., Xie, X.H., Li, B. (2014). Land cover classification using Landsat 8 Operational Land Imager data in Beijing, China. Geocarto International, Vol. 29, 941-951.

[2] Zhu, Z.; Woodcock, C.E. (2014). Continuous change detection and classification of land cover using all available Landsat data. Remote Sensing Environment, Vol.144, 152-171. 
[3] Ejemeyovwi, D. O. (2015). Change Detection in Land use/Land Cover Mapping in Asaba, Niger delta between 1996 and 2015. A Remote Sensing and GIS Approach. British Journal of Environmental Sciences, Vol.3, No.3, 42-61

[4] Wilkie, D.S. and Finn, J.T. (1996). Remote Sensing Imagery for Natural Resources Monitoring. Columbia University Press, New York. Pp295

[5] Briney, A. (2008). An overview of Geographical Information Systems.http://geography.about.com/od/geographyinter/a/gisoverview.htm. (Accessed 25 September 2014)

[6] Zonneveld, I. S. (1979). Land evaluation and landscape science. Volume 11.4 of ITC textbook International Institute of GeoInformation Science and Earth Observations (ITC) Enschede

[7] Miller, G. T. (1996). Living in the Environment. Principles, Connections and Solutions. Wardsworth. UK.

[8] Xiaomei, Y. and Ronqing, L.Q.Y. (1999). Change Detection Based on Remote Sensing InformationModel and its Application to Coastal Line of Yellow River Delta - Earth Observation Center, NASDA, China.

[9] Collins, M.G., Steiner, F.R. and Rushman, M.J. (2001). Land-use suitability analysis in the United States: historical development and promising technological achievements. Environmental Management Vol. 28 No.5, $611-621$.

[10] Malczewski J. (2004). GIS-based land-use suitability analysis: a critical overview. Progress in Planning Vol.62 No.1, 3-65

[11] Hopkins, L. (1977). Methods for generating land suitability maps: a comparative evaluation. Journal for American Institute of Planners 34(1), 19 - 29.

[12] Jiang, H., and Eastman, J.R. (2000). Application of fuzzy measures in multi-criteria evaluation in GIS. International Journal of Geographical Information System, Vol.14, 173 - 184.

[13] Adam, E., Mutanga, O., Odindi, J., Abdel-Rahman, E.M. (2014). Land-use/cover classification in a heterogeneous coastal landscape using Rapid Eye imagery: Evaluating the performance of random forest and support vector machines classifiers. International Journal of Remote Sensing Vol.35, 3440-3458.

[14] Gong, P., Wang, J., Yu, L., Zhao, Y.C., Zhao, Y.Y., Liang, L., Niu, Z.G., Huang, X.M., Fu, H.H. and Liu, S. (2013). Finer resolution observation and monitoring of global land cover: First mapping results with Landsat TM and ETM+ data. International Journal of Remote Sensing, Vol.34, 2607-2654.

[15] Yacouba D., Hu, G. and Wen, X. (2010). Assessment of Land Use Cover Changes Using NDVI and DEM in Puer and Simao Counties, Yunnan Province, China.Report and Opinion, Vol.2 No.9, 7 - 16.

[16] Im, J., and Jensen, J. R. (2005). A change detection model based on neighborhood correlation image analysis and decision tree classification. Remote Sensing Environment. 99, 326 - 340.

[17] El Baroudy, A. A. (2011). Monitoring land degradation using remote sensing and GIS techniques in an area of the middle Nile Delta, Egypt. Catena Vol.87 No.2, 201-208.

[18] Liberti, M., Simoniello, T., Carone, M.T., Coppola, R., Emilio, M.D., and Macchiato, M. (2009). Mapping badland areas using LANDSAT TM/ETM satellite imagery and morphological data. Geomorphology Vol.106, $333-343$

[19] Gao, J., and Liu, Y. (2008). Mapping of land degradation from space: a comparative study of Landsat ETM+ and ASTER data. International Journal of Remote Sensing, 29 (14), 4029 - 4043.

[20] Chafer, C. (2008). A comparison of fire severity measures: an Australian example and implications for predicting major areas of soil erosion. Catena Vol.74, 235 - 245.

[21] Geerken, R., and Ilawi, M. (2004). Assessment of rangeland degradation and development of a strategy for rehabilitation. Remote Sensing of Environment, Vol.90 No.4, 490-504

[22] Lu, D., Batistella, M., Mausel, P., Moran, E. (2007). Mapping and monitoring land degradation risks in the Western Brazilian Amazon using multitemporal Landsat TM/ETM+ images. Land Degradation and Development Vol.18, 41 - 54.

[23] Mathieu, R., Cervelle, B., Remy, D., Pouget, M. (2007). Field-based and spectral indicators for soil erosion mapping in semi-arid Mediterranean environments (Coastal Cordillera of central Chile). Earth Surf. Proc. Land. Vol.32, $13-31$.

[24] Aiyemafuge, I. (2014). History of Ilaje, Ilaje Community Welfare Association. Available at www.ilajecwa.org.uk/history.htm (Accessed, $13^{\text {th }}$ June, 2014). 
[25] Zandbergen, P. (2008). Applications of Shuttle Radar Topography Mission Elevation Data, Geography Compass, 2/5, pages $1401-1431,10.1111 /$ j.1749-8198.2008.00154.x

[26] Sanders, B. F. (2007). Evaluation of on-line DEMs for flood inundation modelling, Advances in Water Resources Vol.30, 1831 - 1843.

[27] Demirkesen, A. C., Evrendilek, F., Berberoglu, S. and Kilic, S. (2007). Coast flood risk analysis using Landsat-7 ETM+ imagery and SRTM DEM: a case study of Izmir, Turkey, Environmental Monitoring and Assessment, Vol.131 No.1-3, 293 - 300.

[28] National Aeronautics and Space Administration (NASA) (2011a). The Landsat Program, available at http://landsat.gsfc.nasa.gov/about/landsat1.html. (Accessed April 2, 2014)

[29] National Aeronautics and Space Administration (NASA) (2011b). Landsat 4 TM, available at http://landsat.gsfc.nasa.gov/about/landsat4.html (Accessed April 2, 2014)

[30] National Aeronautics and Space Administration (NASA) (2011c). Landsat 7 ETM+, available at http://landsat.gsfc.nasa.gov/about/landsat7.html. (Accessed April 2, 2014)

[31] Liew, S.C. (2001). Remote Sensing Tutorial, Principles of Remote Sensing, Centre for Remote Imaging, Sensing and Processing, National University of Singapore, available at http://www.crisp.nus.edu.sg/ research/tutorial/intro.htm. (Accessed October 10, 2014)

[32] National Aeronautics and Space Administration (NASA) (2011d). Landsat 6 ETM+, available at http://landsat.gsfc.nasa.gov/about/landsat6.html. (Accessed April 2, 2014)

[33] United States Geological Survey (USGS) (2011a). Earth Explorer Help Documentation, Version 0.5, available at http://edcsns17.cr.usgs.gov/NewEarthExplorer/documents/helptutorial.pdf. (Accessed October 30, 2014)

[34] Geospatial Innovation Facility (GIF) (2008).RS/GIS Quick Start Guides, Landsat Spectral Band Information, available at http://gif.berkeley.edu/documents/Landsat\%20Band\%20Information.pdfLast (Accessed September 20, 2014.)

[35] Ho, L. T. K., Umitsu, M. and Yamaguchi, Y. (2010). Flood hazard mapping by satellite images and SRTM DEM in the Vu Gia - Thu Bon Alluvial Plain, Central Vietnam, International Archives of the Photogrammetry, Remote Sensing and Spatial Information Science, 38, Part 8, Kyoto, Japan, available at http://www.isprs.org/proceedings/XXXVIII/part8/headline/TS-27/W01OH2_20100309140832.pdf, (Accessed November 30, 2014)

[36] United States Geological Survey (USGS) (2011b). Earth Explorer Landsat Product Type Descriptions, available at http://edcsns17.cr.usgs.gov/helpdocs/landsat/product_descriptions.html (Accessed October 30, 2014)

[37] United States Geological Survey (USGS) (2011c). Landsat Missions, Frequently Asked Questions about the Landsat Missions, available at http://landsat.usgs.gov/band_designations_landsat_satellites.php (Accessed November 5, 2014)

[38] United States Geological Survey (USGS) (2011d). Landsat Missions: Panchromatic Image Sharpening of landsat 7 ETM+, available at http://landsat.usgs.gov/panchromatic_image_sharpening.php (Accessed November 10, 2014)

[39] Rouse, J.W., Haas R. H., Schell J. A. \& Deering D. W. (1974). Monitoring vegetationsystems in the Great Plains with ERTS. In: Fraden S.C., Marcanti E.P. \& Becker M.A. (eds), Third ERTS-1 Symposium, 10 14 December 1973, NASA SP-351, Washington D.C. NASA, 309 - 317

[40] Adeyewa Z.D. (2007). Applications of Satellites in Monitoring Vegetation: The African Perspective, SAN. Conference, 3-6 September, Federal University of Technology, Akure

[41] Kwak, Y and Kondoh, A. (2008). A study on the extraction of multi-factor influencing floods from RS image and GIS data; a case study in Nackdong Basin, South Korea", The International Archives of The Photogrammetry, Remote Sensing and Spatial Information Sciences, ISPRS Congress Beijing 2008, 37, Part B8, Commission VIII, pages 421- 426, available at http://www.isprs.org/proceedings/XXXVII/congress/8_pdf/2_WG-VIII-2/50.pdf. (Accessed 30 ${ }^{\text {th }}$ April, 2014) 
[42] Environmental Systems Research Institute (ESRI) (2009a). ArcGIS Desktop 9.3 Help, Creating a depressionless DEM, available at http://webhelp.esri.com/arcgiSDEsktop/9.3/index.cfm?TopicName= Creating_a_depressionless_DEM. (Accessed July 16, 2014)

[43] Environmental Systems Research Institute (ESRI) (2009b). ArcGIS Desktop 9.3 Help, Understanding multivariate classification, available at http://webhelp.esri.com/arcgisdesktop/9.3/ index.cfm?id=6097\&pid=6096\&topicname=Under standing_multivariate_classification. (Accessed July 16, 2014)

[44] University Corporation for Atmospheric Research (UCAR) (2010). Flash Flood Early Warning System Reference Guide, United States of America, available at http://www.meted.ucar.edu/hazwarnsys/ffewsrg/ FF_EWS.frontmatter.pdf.Last Accessed November 18, 2011. 


\begin{abstract}
Authors

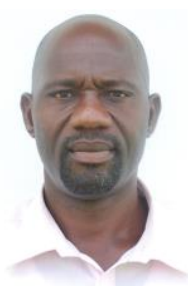

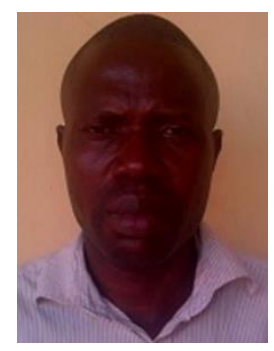

\title{
Akomolafe James Kolawole
}

Akomolafe James Kolawole graduated from the Department of Civil and Environmental Engineering, Federal University of Technology Akure. He is currently a staff of Works and Physical Planning Unit at Ondo State University of Science and Technology Okitipupa Ondo State.His areas of interest include Water Resources Planning and Management

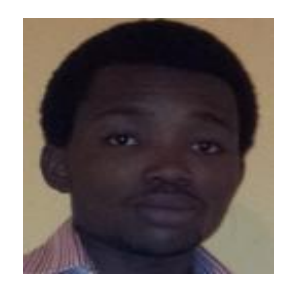

\section{Ajibade Fidelis Odedishemi}

Ajibade Fidelis Odedishemi is currently an Assistant Lecturer in the Department of Civil and Environmental Engineering, Federal University of Technology, Akure, Ondo State Nigeria. He obtained B.Eng. (Agricultural Engineering - Soil and Water Engineering option) in 2009 from University of Ilorin, Ilorin, Nigeria and Master degree in Civil Engineering from the Federal University of Technology, Akure, Nigeria in 2013. His research interests include Water and Wastewater Engineering, Solid Waste Management and Waste to Bioresource

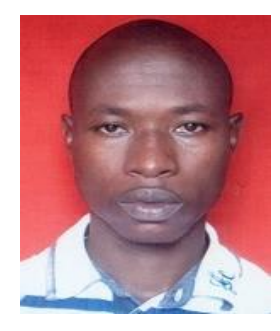

\section{Fabeku Blessing Bolarinwa}

Fabeku Blessing Bolarinwa graduated from the Department of Meteorology and Climate Science. He is currently a staff of Meteorology Unit, Ondo State University of Science and Technology, Okitipupa, Ondo State, Nigeria. His areas of interest include Meteorology, GIS and Remote Sensing 